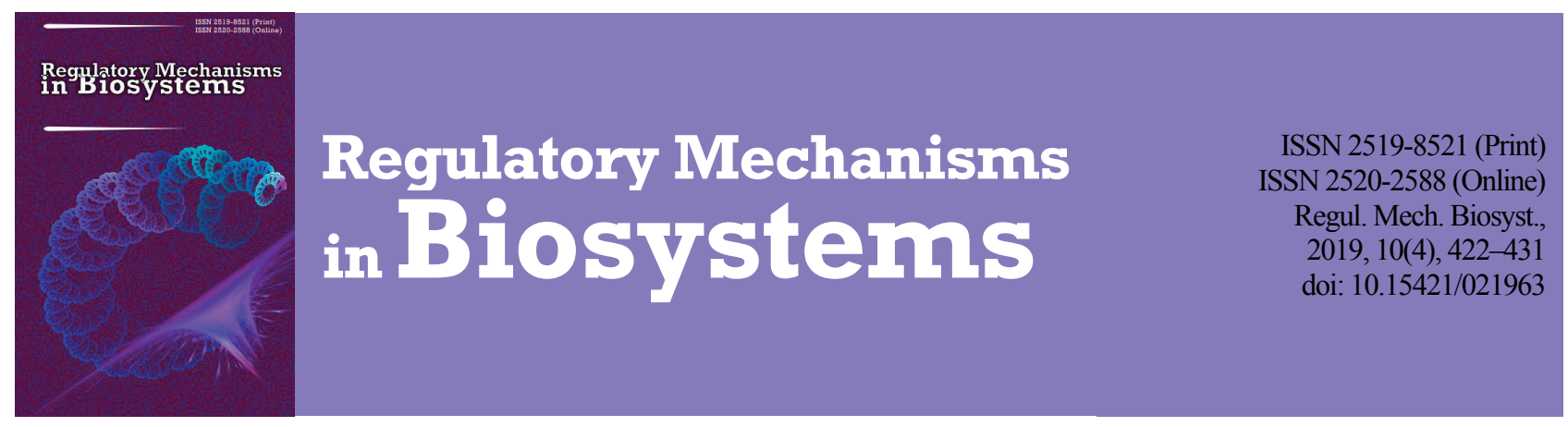

\title{
Manifestations of allostatic load in residents of radiation contaminated areas aged 18-24 years
}

\author{
V. L. Sokolenko, S. V. Sokolenko \\ Bohdan Khmelnytsky National University of Cherkasy, Chercasy, Ukraine
}

Article info

Received 08.09.2019

Received in revised form

02.10 .2019

Accepted 03.10.2019

Bohdan Khmelnytsky

National University

of Cherkasy,

Shevchenko st., 81 ,

Chercasy, 18031 ,

Ukraine.

Tel.: +38-067-869-17-91

E-mail: sokolen-

ko@ukr.net

\section{Sokolenko, V. L., \& Sokolenko, S. V. (2019). Manifestations of allostatic load in residents of radiation contaminated areas aged 18 24 years. Regulatory Mechanisms in Biosystems, 10(4), 422-431. doi:10.15421/021963}

\begin{abstract}
We studied the features of allostatic load (AL) in 100 students aged 18-24 years old who, from birth to adulthood, lived in the territories assigned to the IV radiation zone after the Chornobyl accident (density of soil contamination by isotopes ${ }^{137} \mathrm{Cs} 3.7-18.5 \cdot 10^{4} \mathrm{~Bq} / \mathrm{m}^{2}$ ) and underwent prolonged exposure to small doses of ionizing radiation. The examined students did not have any clinical signs of the immune-neuroendocrine system dysfunction. 50 people had signs of vegetative-vascular dystonia syndrome (VVD), 48 had signs of moderate hyperthyroidism and 21 had signs of moderate hypothyroidism. During the examination session, as a factor of additional psycho-emotional load, in 66 of the examined the immunoregulatory index CD4+/CD8+ went below the lower limit of the homeostatic norm, in 62 of the examined low density lipoprotein cholesterol (LDL-C) exceeded the upper level. The relative risk (RR) and attributable risk (AR) of the participation of potential secondary factors of allostatic load formation in CD4+/CD8+ immunoregulatory index going below the lower limit were calculated. The presence of statistically significant relative risk of participation in the formation of suppression of the index CD4+/CD8+: the state of hyperthyroidism, state of hypothyroidism, vegetative-vascular dystonia syndrome, higher than normal LDL-C. When the examined students combined the signs of hyperthyroidism, vegetative-vascular dystonia syndrome and higher level of LDL-C; with combination of signs of hypothyroidism, vegetative-vascular dystonia syndrome and higher level of LDL-C. The attributable risk in all cases exceeded 0.10, which confirmed the importance of some of these factors and their complexes in the formation of the effect of reduced immunoregulatory index. The CD4+/CD8+ index can be considered an important biomarker of $\mathrm{AL}$ and premature age-related changes in the immune system in residents of radiation-contaminated areas. The risk of $\mathrm{AL}$ formation in the case of occurrence of a complex of mediated secondary biomarkers (vegetative-vascular dystonia syndrome, thyroid dysfunction, hypercholesterolemia) is higher compared to their individual significance.
\end{abstract}

Keywords: Chornobyl accident; low doses of radiation; emotional stress; immune-neuroendocrine complex; biomarkers; immunosenescence; $\mathrm{CD} 4+/ \mathrm{CD} 8+$.

\section{Introduction}

Humanity is constantly under the influence of many harmful environmental factors that lead to adverse health effects and/or cause disruption of the regulation and dynamics of certain homeostatic indicators. Sensitivity to extreme conditions is determined by many individual characteristics genetic, psychological or physiological (Belsky \& Pluess, 2009). The study of adaptation to exogenous factors is one of the most important tasks in the field of human biomonitoring - this makes it possible to identify leading biomarkers of potential pathogenic changes in the body (Rossnerova et al., 2017). Since the 1960s, the concept of adaptation in biology and ecology has been understood as an evolutionary process through which the body optimally adapts to certain living conditions (Dobzhansky, 1968). Genetically determined adaptation provides a reproductive advantage to the population in a particular environment, it is a reaction to existing prevailing environmental factors, and it is formed over a long period. On the other hand, it may reduce the ability to adapt to subsequent environmental changes, that is, to be a prerequisite for maladaptation. Therefore, the dominance of non-hereditary adaptation in humanity gives it certain advantages (Moran, 2018).

The question of the possibility of adaptation of the human body to chronic radiation exposure and the existence of the phenomenon of radiation hormesis is currently being discussed. Supporters believe that lowdose pre-irradiation causes adaptive response, thereby increasing resistance to high doses (Baldwin \& Grantham, 2015).
Signs of radiation hormesis have been noted for many biological objects, there are studies for certain groups of people (Gourabi \& Mozdarani, 1998) and human lymphocytes in vitro (Olivieri et al., 1984; Rithidech \& Scott, 2008). In particular, there is a decrease in cases of cancer in individuals previously irradiated with chronic low doses (Esteller \& Herman, 2002; Chen et al., 2007; Zölzer et al., 2017), a reduced degree of DNA damage in the long term compared with control (Zölzer et al., 2015; Rossnerova et al., 2016), certain structural changes in lymphocytes that can be classified as manifestations of the adaptive response (Zölzer et al., 2012).

On the other hand, various sources described cases of negative effects (at the level of reproductive functions, accumulation of genetic and epigenetic changes, manifestations of carcinogenic and immunodeficiency processes, premature aging and reduction of life expectancy) of chronic radiation exposure in animals both in laboratory conditions and in the wild after the Chornobyl accident (Tang et al., 2016). Data are available on induction under the influence of low-dose ionizing radiation (LDIR) or low-doserate ionizing radiation (LDRIR) of cancer (Shah et al., 2012; Davis et al., 2015; Leuraud et al., 2015) and cardiovascular diseases (Sumner, 2007) and formation of long-term psychological effects in humans (Pastel, 2002). Such publications support the linear non-threshold theory which says that ionizing radiation is harmful, starting with minimal doses (Rossnerova et al., 2017). Thus, the question of the presence or effectiveness of adaptive responses to radiation remains debatable. Clearly, radiation is a recognized stress factor (Nylund et al., 2014). Stress is any change in a person's homeostasis due to the action of real or potentially dangerous 
factors. An important component of the normal response to stress is the phase of recovery of physiological parameters to homeostatic values. A special consequence of a stress reaction is allostasis, when, unlike homeostasis, after the stressor expiration, the indicators do not return to their initial levels, although, under these conditions, they are optimal (Cool \& Zappetti, 2019).

The stress effect, in which the regulatory systems are not able to restore the indicators to optimal values, is called allostatic load (AL). The consequences of such an allostatic reaction are manifested by various types of biological damage, lead to the depletion of adaptive resources or violations of the regulation of the whole complex of physiological systems, and thus to pathological changes in the body. Thus, allostatic load determines the resistance to stress. Typical factors that can lead to an allostatic load of a person are extreme exogenous factors and social stressors (McEwen \& Stellar, 1993; McEwen, 2007; Juster et al., 2010). Different types of stressors are characterized by different allostatic load and differentially affect various physiological systems (Wiley et al., 2016). However, the mechanisms of their effects on the immune system are similar. This is particularly true of physical and psychological stress (Yang \& Glaser, 2002). Moreover, psychological stress significantly inhibits the effectiveness of adaptive mechanisms to other stressors (Krivoschekov \& Mozolevskaya, 2007), its intensity increases with age (Luz et al., 2003). The allostatic load model is an effective tool for predicting health disorders and is measured on the basis of certain indexed biomarkers, moreover, it is important to make an integral assessment of the functional potential of physiological systems (McEwen \& Stellar, 1993; Juster \& Lupien, 2012). Metabolic, neuroendocrine and cardiovascular parameters were considered to be optimal biomarkers of allostatic load for a while. Recently, immune biomarkers have been increasingly used to evaluate it. It is recommended to consider the age factor here (Juster et al., 2010; Wiley et al., 2016; Cool \& Zappetti, 2019). Dysfunctions of these indicators are, at the same time, typical effects of radiation exposure (Korenev et al., 2009; Minchenko et al., 2013; Bilokur, 2018) and biomarkers of premature aging of the organism (López-Otín et al., 2013; Leonardi et al., 2018; McHugh \& Gil, 2018).

Aging is a complex dynamic process characterized by continuous adaptation of the organism to age-dependent degenerative phenomena (impairment of physiological functions due to structural and functional changes at the molecular level) (Ostan et al., 2008). In fact, aging is the result of the balance between damage to the body over the course of life and its elimination. The rate of aging and the emergence of age-related pathology are modulated by responses to stress and recovery processes that are gradually inhibited at different levels (DNA repair, mitochondrial respiration repair, etc.) (Haigis \& Yankner, 2010). Signs of aging are evident from the onset of reproductive maturity. The process of premature aging is conditioned by a complex of free-radical, metabolic, endocrine and psycho-emotional maladaptive processes, reflecting the imbalance and inconsistent activity of the main homeostatic systems of the organism, as a consequence of the exhaustion of their potential (Hayflick, 2007; Kirkwood \& Shanley, 2010; Rando \& Chang, 2012).

Accelerated aging and increased susceptibility to chronic diseases are facilitated by living in ecologically unfavourable regions and stresses of various nature. Moreover, the positive effects of the achievements of modern medicine can be largely smoothed over (Rajah et al., 2009; Boieva et al., 2018). Recently, a wide range of age-related diseases, including cardiovascular and cancer, have been described for exposed groups of people. Comparison of the theories of biological processes of aging and the effect of ionizing radiation on the human body shows the similarity of the development of free radical processes, metabolic and immune dysfunctions (Richardson, 2009).

For the liquidators of the Chornobyl accident the acceleration of the aging rate depending on the received dose is discovered, the increase of its heterochrony and heterotopia, the pathologizing effect (an increase in the number of diagnosed diseases in long-term observation), the presence of a positive correlation between the biological age and the level of cortisol, pro-inflammatory cytokines in peripheral blood. Moreover, a higher risk of activation of aging processes is observed with irradiation at a young age (Akhaladze, 2016). One of the leading determinants of the following radiation-induced effects, in which the immune system plays an important role, is precisely the age of the victims (Hernández et al., 2015).

Many more questions are raised by the age-related effects of low-dose radiation $(<100 \mathrm{mSv}$ and especially $<10 \mathrm{mSv})$. The risk level for accelerating aging or occurrence of various dysfunctions under these conditions remains a major problem in radiation epidemiology (Orgiazzi, 2015; Akhaladze, 2016). Therefore, young people from the territories of enhanced radioecological control must be under permanent medical supervision. Unfortunately, in medical practice, up to now, attention is paid mainly to the expressed clinical indicators in the irradiated cohorts of the population, which limits the possibility of preventive measures (Juster \& Lupien, 2012). Thus, the concept of maladaptation and premature aging of the organism, in particular, under conditions of radiation exposure, are closely related. Finding their common biomarkers (at the allostatic load level) and analyzing reciprocal interactions (especially in the initial stages of dysfunction development) are significant means of identifying individuals at risk of stress-induced dysfunction and preventing epidemiological risks for certain population cohorts (Juster et al., 2010).

So, the potential factors for maladaptation development and interaction between them receive little attention. Among the prognosis criteria, which characterize the involvement of a particular factor in the formation of human health disorders or the development of various dysfunctions, the relative and attributable risks are indicated (Zaretskaya, 1983; Zaporozhan et al., 2010). A specific feature of these indicators is the ability to be used as prognostic markers when relevant dysfunctions occur only in some individuals in a particular cohort.

The purpose of the study was to find out the values of some particular indicators of lipid metabolism, thyroid status, vegetative-vascular dysfunctions and immune system as markers of allostatic load in persons aged 18 24 years, who lived for a long time in the territories of enhanced radioecological control (by calculation the relative risk).

\section{Materials and methods}

We analyzed the level of cortisol, lipid metabolism, thyroid status, redox homeostasis and immune systems of 100 students aged 18-24 years, who from birth to adulthood had lived in the territories of enhanced radiation monitoring with soil contamination by isotopes ${ }^{137} \mathrm{Cs} 3.7 \cdot 10^{4}-$ $18.5 \cdot 10^{4} \mathrm{~Bq} / \mathrm{m}^{2}$. The pollution of the territories was caused by the disaster at the Chornobyl Nuclear Power Plant in 1986. There were no persons with clinical manifestations of immune-neuroendocrine disorders in the examined group. In conducting the research, the ethical principles of the European Convention and the Declaration of Helsinki were followed, written approval of the examined persons for test and the subsequent data release was obtained.

Biomaterial sampling techniques, reagents and research methods used have been described in detail in previous publications: evaluation of erythrocyte (AB0, Rhesus) and serum (haptoglobin Hp system) genetic blood systems (Sokolenko, 2016b), lipid metabolism (Sokolenko \& Sokolenko, 2017b), the immune system and oxidative-antioxidant status (Sokolenko et al., 2018), cortisol and thyroid status (Sokolenko \& Sokolenko, 2019). The diagnosis of vegetative-vascular dystonia (VVD) syndrome was set by the doctors of the sanatorium "Edem" at the university.

The relative risk (RR) is calculated as the ratio of the event probability in a group with some dysfunction $\mathrm{R}_{1}(\mathrm{a} /(\mathrm{a}+\mathrm{b}))$ to the event probability in a group without a specific dysfunction $R_{0}(c /(c+d))$. Thus, the formula for calculating relative risk is as follows: $R R=R_{1} / R_{0}=$ $(a /(a+b)) /(c /(c+d))$. In our case: $a-$ the number of persons in a group with a certain dysfunction, in which the analyzed index went beyond the homeostatic norm; $b$ - the number of persons in a group with a certain dysfunction, in which the analyzed index didn't exceed within the limits of the homeostatic norm; $\mathrm{c}$ - the number of persons in a group without a certain dysfunction, in which the analyzed index went beyond the homeostatic norm; $\mathrm{d}$ - the number of persons in a group without a certain dysfunction, in which there was no output of the analyzed index beyond the limits of the homeostatic norm.

At values of the relative risk higher than 1.0, a factor was considered to increase the dysfunction manifestation. The limits of $95 \%$ confidence interval (CI 95\%) were evaluated. If the confidence interval did 
not contain 1.00 , we made a conclusion about a statistical significance of the relationship between the risk factor (s) and the dysfunction manifestation with a probability of error $\mathrm{P}<0.05$.

The assessment of difference validity in qualitative characteristics in the groups was performed using the Pearson criteria $\chi^{2}$. The critical value of $\chi^{2}$ for the four-field table (with the degree of freedom 1) -3.84 $(\mathrm{P}<0.05), 6.63(\mathrm{P}<0.01), 10.00(\mathrm{P}<0.001)$. In the case of having less than 10 people in a sample, Yates's correction was used; for less than 5 people, Fisher's exact test was taken into account (Grjibovski, 2008).

The etiological fraction (attributable risk, AR) was calculated according to the formula: $\mathrm{AR}=(\mathrm{x}-\mathrm{y}) /(1-\mathrm{y})$, where $\mathrm{x}$ is the number of people with reduced immunoregulatory index in a group with a certain physiological dysfunction; $\mathrm{y}$ - the number of people with a reduced immunoregulatory index in the group without the physiological dysfunction.

The attributable risk gave an opportunity to assess objectively the causative role of one or more factors in the formation of a certain dysfunction of the immune system (in our case, the output of the immunoregulatory index below the norm limits) in the analyzed cohort of the examined people, if for these factors $\mathrm{RR}$ was $>1.00$. The indicator AR was considered to be significant when more than 0.10 (Zaretskaya, 1983).

\section{Results}

Among the 100 examined persons, there were 50 with signs of vegetative-vascular dystonia syndrome, 48 persons had signs of moderate hyperthyroidism and 21 had signs of moderate hypothyroidism. During the examination session, as a factor of additional psycho-emotional load, 66 people showed the immunoregulatory index CD4+/CD8+ below the lower limit of the homeostatic norm, 62 people had the level of total cholesterol (TC) and low density lipoprotein cholesterol (LDL-C) over the upper limit of the norm.

We calculated the participation of some definite potential factors of allostatic load formation in the reduction (with the withdrawal of the lower limit of norm during additional emotional load) of the immunoregulatory index $\mathrm{CD} 4+/ \mathrm{CD} 8+$. It was found that the state of hyperthyroidism causes $\mathrm{RR}=1.69\left(\mathrm{CI} 95 \% 1.07-2.65 ; \chi^{2}=5.12 ; \mathrm{F}=7.6 \cdot 10^{-3}\right)$; the state of hypothyroidism: $\mathrm{RR}=2.16$ (CI 95\% 1.39-3.34; $\chi^{2}=7.33$; $\mathrm{F}=3.4 \cdot 10^{-4}$ ). Vegetative-vascular dystonia syndrome causes $\mathrm{RR}=2.0$ (CI 95\% 1.44-2.78; $\chi^{2}=19.65 ; \mathrm{F}=2.4 \cdot 10^{-6}$ ); low density lipoprotein cholesterol increased over the norm causes: $\mathrm{RR}=2.55$ (CI 95\% 1.57 $4.14 ; \chi^{2}=24.07 ; \mathrm{F}=1.0 \cdot 10^{-6}$, Table 1). Analysis of the complex effect of factors showed that the combination of the signs of hyperthyroidism, vegetative-vascular dystonia syndrome and increased level of low density lipoprotein, gives the relative risk of going beyond the lower limit of the norm in immunoregulatory index $\mathrm{RR}=3.03$ (CI 95\% 1.60-5.74; $\chi^{2}=11.87 ; \mathrm{F}=2 \cdot 0^{\cdot} 10^{-5}$ ). Combining signs of hypothyroidism, vegetative-vascular dystonia syndrome, and increased low density lipoprotein cholesterol, $\mathrm{RR}=3.43\left(\mathrm{CI} 95 \% 1.84-6.39 ; \chi^{2}=13.65 ; \mathrm{F}=2.3 \cdot 10^{-6}\right)$.

The attributable risk in all cases (with respect to the reduced $\mathrm{CD} 4+/ \mathrm{CD} 8+$ ) exceeded 0.10 . For the state of hyperthyroidism $\mathrm{AR}=0.61$; for the state of hypothyroidism $\mathrm{AR}=0.31$; with syndrome of vegetativevascular dystonia $\mathrm{AR}=0.51$; with increased over norm low density lipoprotein cholesterol $\mathrm{AR}=0.77$; when combined signs of hyperthyroidism, vegetative-vascular dystonia syndrome and increased level of low density lipoprotein cholesterol $\mathrm{AR}=0.70$; when combined signs of hypothyroidism, vegetative-vascular dystonia syndrome and increased level of low density lipoprotein cholesterol $\mathrm{AR}=0.59$ (Table 1$)$.

Assessment of the confidence interval confirmed the importance of all the analyzed risk factors (both individual and in combinations) in the formation of the effect of reducing the index CD4+/CD8+. Assessment of the reliability of differences in qualitative characteristics in groups with or without a risk factor was confirmed by a statistically significant $\chi^{2}$ and Fisher's calculated criterion (Table 1).

We calculated the significance of participation of thyroid status specifics and lipid profile of the examined people in the formation of vegetative-vascular dystonia syndrome: the relative risk of its development is significant for signs of hyperthyroidism $(\mathrm{RR}=2.40$; CI 95\% 1.19-4.84; $\left.\chi^{2}=5.43 ; \mathrm{F}=3.9 \cdot 10^{-3}\right)$, hypothyroidism $(\mathrm{RR}=3.59 ; \mathrm{CI} 95 \% 1.56-6.32$; $\left.\chi^{2}=11.12 ; \mathrm{F}=4.0 \cdot 10^{-5}\right)$ and increased low density lipoprotein cholesterol $\left(\mathrm{RR}=9.60 ; \mathrm{CI} 95 \% 3.21-28.70 ; \chi^{2}=40.79 ; \mathrm{F}=7.8 \cdot 10^{-12}\right)$. The attributable risk in all cases exceeded 0.1 ( $\mathrm{AR}=0.73$ for the state of hyperthyroidism; $\mathrm{AR}=0.59$ for the state of hypothyroidism; $\mathrm{AR}=0.94$ with low density lipoprotein cholesterol elevated) (Table 2).

Assessment of the confidence interval confirmed the importance of all the analyzed risk factors in the formation of vegetative-vascular dystonia syndrome. The assessment of the reliability of differences in qualitative characteristics in groups with or without a risk factor was confirmed by a statistically significant $\chi^{2}$ and Fisher test (Table 2).

\section{Table 1}

Relative risk and attributable risk (etiological fraction) of the participation of some definite factors and their combinations in manifestations of allostatic load at the level of CD4+/CD8+ immunoregulatory index

\begin{tabular}{|c|c|c|c|c|c|c|c|c|}
\hline \multirow{2}{*}{ Risk factor } & \multirow{2}{*}{ Presence } & \multicolumn{2}{|c|}{ Number of people among examined, $\mathrm{n}$} & \multirow{2}{*}{$\begin{array}{c}\text { Relative } \\
\text { risk RR, P }\end{array}$} & \multirow{2}{*}{$\begin{array}{l}\text { Confidence } \\
\text { interval CI 95\% }\end{array}$} & \multirow{2}{*}{$\begin{array}{c}\chi^{2} \\
\text { for trend, } P\end{array}$} & \multirow{2}{*}{$\begin{array}{l}\text { Fisher's } \\
\text { exact test } \mathrm{F}\end{array}$} & \multirow{2}{*}{$\begin{array}{l}\text { Attributable } \\
\text { risk AR }\end{array}$} \\
\hline & & $\mathrm{CD}^{+} / \mathrm{CD}^{+}$reduced & $\mathrm{CD}^{+} / \mathrm{CD}^{+}$within the norm & & & & & \\
\hline Hyperthyroidism & $\begin{array}{l}\text { present } \\
\text { missing }\end{array}$ & $\begin{array}{l}34(\mathrm{a}) \\
13(\mathrm{c})\end{array}$ & $\begin{array}{l}14(\mathrm{~b}) \\
18(\mathrm{~d})\end{array}$ & $\begin{array}{c}1.69 \\
\mathrm{P}<0.05\end{array}$ & $1.07-2.65$ & $\begin{array}{c}5.12 \\
\mathrm{P}<0.05\end{array}$ & $7.6 \cdot 10^{-3}$ & 0.61 \\
\hline Hypothyroidism & $\begin{array}{l}\text { present } \\
\text { missing }\end{array}$ & $\begin{array}{l}19(\mathrm{a}) \\
13(\mathrm{c})\end{array}$ & $\begin{array}{l}2(\mathrm{~b}) \\
18(\mathrm{~d})\end{array}$ & $\begin{aligned} & 2.16 \\
\mathrm{P} & <0.05\end{aligned}$ & $1.39-3.34$ & $\begin{array}{c}7.33 \\
\mathbf{P}<0.01\end{array}$ & $3.4 \cdot 10^{-4}$ & 0.31 \\
\hline $\begin{array}{l}\text { Vegetative-vascular } \\
\text { dystonia syndrome }\end{array}$ & $\begin{array}{l}\text { present } \\
\text { missing }\end{array}$ & $\begin{array}{l}44(\mathrm{a}) \\
22(\mathrm{c})\end{array}$ & $\begin{array}{l}6(\mathrm{~b}) \\
28(\mathrm{~d})\end{array}$ & $\begin{array}{c}2.00 \\
\mathrm{P}<0.05\end{array}$ & $1.44-2.78$ & $\begin{array}{c}19.65 \\
\mathrm{P}<0.001\end{array}$ & $2.4 \cdot 10^{-6}$ & 0.51 \\
\hline Increased LDL-C & $\begin{array}{l}\text { present } \\
\text { missing }\end{array}$ & $\begin{array}{l}50(\mathrm{a}) \\
12(\mathrm{c})\end{array}$ & $\begin{array}{l}12(\mathrm{~b}) \\
26(\mathrm{~d})\end{array}$ & $\begin{aligned} & 2.55 \\
\mathrm{P} & <0.05\end{aligned}$ & $1.57-4.14$ & $\begin{array}{c}24.07 \\
\mathrm{P}<0.001\end{array}$ & $1.0 \cdot 10^{-6}$ & 0.77 \\
\hline $\begin{array}{l}\text { Combination of hyperthyroidism, } \\
\text { VVD syndrome, increased LDL-C }\end{array}$ & $\begin{array}{l}\text { present } \\
\text { missing }\end{array}$ & $\begin{array}{l}23 \text { (a) } \\
7 \text { (c) }\end{array}$ & $\begin{array}{l}3(\mathrm{~b}) \\
17(\mathrm{~d})\end{array}$ & $\begin{array}{c}3.03 \\
\mathrm{P}<0.05\end{array}$ & $1.60-5.74$ & $\begin{array}{c}11.87 \\
\mathrm{P}<0.001\end{array}$ & $2.0 \cdot 10^{-5}$ & 0.70 \\
\hline $\begin{array}{l}\text { Combination of hypothyroidism, } \\
\text { VVD syndrome, increased LDL-C }\end{array}$ & $\begin{array}{l}\text { present } \\
\text { missing }\end{array}$ & $\begin{array}{l}17 \text { (a) } \\
7(\mathrm{c})\end{array}$ & $\begin{array}{l}0(\mathrm{~b}) \\
17(\mathrm{~d})\end{array}$ & $\begin{array}{c}3.43 \\
\mathrm{P}<0.05\end{array}$ & $1.84-6.39$ & $\begin{array}{c}13.65 \\
\mathrm{P}<0.001\end{array}$ & $2.3 \cdot 10^{-6}$ & 0.59 \\
\hline
\end{tabular}

\section{Table 2}

Relative risk and attributable risk (etiological fraction) of participation of separate factors in manifestations of allostatic load at the level of formation of vegetative-vascular dystonia syndrome

\begin{tabular}{|c|c|c|c|c|c|c|c|c|}
\hline \multirow{2}{*}{ Risk factor } & \multirow{2}{*}{ Presence } & \multicolumn{2}{|c|}{ Number of people among examined, $n$} & \multirow{2}{*}{$\begin{array}{l}\text { Relative } \\
\text { risk RR }\end{array}$} & \multirow{2}{*}{$\begin{array}{c}\text { Confidence } \\
\text { interval CI 95\% }\end{array}$} & \multirow{2}{*}{$\begin{array}{c}\chi^{2} \\
\text { for trend, } P\end{array}$} & \multirow{2}{*}{$\begin{array}{c}\text { Fisher's } \\
\text { exact test F }\end{array}$} & \multirow{2}{*}{$\begin{array}{c}\text { Attributable } \\
\text { risk AR }\end{array}$} \\
\hline & & with VVD syndrome & without VVD syndrome & & & & & \\
\hline \multirow{2}{*}{ Hyperthyroidism } & present & $26(a)$ & $22(\mathrm{~b})$ & 2.40 & \multirow{2}{*}{$1.19-4.84$} & 5.43 & \multirow{2}{*}{$3.9 \cdot 10^{-3}$} & \multirow{2}{*}{0.73} \\
\hline & missing & $7(\mathrm{c})$ & $24(d)$ & $\mathrm{P}<0.05$ & & $\mathrm{P}<0.05$ & & \\
\hline \multirow{2}{*}{ Hypothyroidism } & present & 17 (a) & 7 (b) & 3.59 & \multirow{2}{*}{$1.56-6.32$} & 11.12 & \multirow{2}{*}{$4.0 \cdot 10^{-5}$} & \multirow{2}{*}{0.59} \\
\hline & missing & $7(\mathrm{c})$ & $24(\mathrm{~d})$ & $\mathrm{P}<0.05$ & & $\mathrm{P}<0.001$ & & \\
\hline \multirow{2}{*}{ Increased LDL-C } & present & 47 (a) & 15 (b) & 9.60 & \multirow{2}{*}{$3.21-28.70$} & 40.79 & \multirow{2}{*}{$7.8 \cdot 10^{-12}$} & \multirow{2}{*}{0,94} \\
\hline & missing & $3(\mathrm{c})$ & $35(\mathrm{~d})$ & $\mathrm{P}<0.05$ & & $\mathrm{P}<0.001$ & & \\
\hline
\end{tabular}




\section{Discussion}

Low-dose ionizing radiation (LDIR) is considered to be an equivalent (absorbed) radiation dose of less than $100 \mathrm{mSv}$ (100 mGy) (Tang et al., 2016). Students who came for studying from radiation contaminated territories ${ }^{137} \mathrm{Cs} 3.7 \cdot 10^{4}-18.5 \cdot 10^{4} \mathrm{~Bq} / \mathrm{m}^{2}$ are a special cohort of the Ukrainian population. On the one hand, the passport dose calculated for them usually did not exceed indicators that are in the low dose range. On the other hand, they have been exposed to chronic radiation from birth to adulthood, and the question of the long-term consequences of such a process remains debatable. Indeed, the characteristics of the effects of low-dose radiation exposure are ambiguous: from negative (assuming linear dependence and no threshold) to the recognition of radiation hormesis and the presence of a radioadaptive response (Calabrese \& O'Connor, 2014; Baldwin \& Grantham, 2015; Sacks et al., 2016).

The mechanisms of adaptive response and radiation hormesis in chronic radiation exposure are being discussed, perhaps they will be realized at the level of transcriptional processes and epigenetic changes (Bernal et al., 2013; Sokolov \& Neumann, 2016). In general, the mechanisms associated with adapting to intermediate and low levels of radiation are thought to be different from the mechanisms required to survive at high doses. The irritation that should cause an adaptive response may not reach the threshold level (Roff, 2012). This is confirmed by separate studies of the radiosensitivity of cells in vitro. In addition, it is advisable to be careful about interpreting the terms "radiosensitive" or "adaptive" as they do not give an indication of whether the response to the radiation is useful or harmful (Shi et al., 2016).

The period of 30 years after the Chornobyl accident was sufficient to generate adaptive changes in many organisms, in particular, certain systematic groups of those vertebrates which do not have a long generation time (Galván et al., 2014; Møller \& Mousseau, 2016).

It is argued that the effects of chronic radiation exposure may depend on the duration of the factor effect on the level of a particular population and possible accompanying factors (Rossnerova et al., 2017). Such a cohort is formed by persons who have lived in radionuclide contaminated territories for a long time and then were enrolled in higher education institutions where they had to adapt to new living and study conditions. The implementation of primary adaptation in this group is maximally realized in the first year of study, however, in the second to fourth years there are periods of intense psycho-emotional load due to the examination sessions. It can be predicted that the stressful effect of exams depends to a large extent on the capacity of the adaptive potential generated during residence in the areas of enhanced radioecological control. Accordingly, this cohort runs the risk of forming an allostatic load.

Previously, we showed that the students in the experimental group during the intersession period had immune system indicators within the homeostatic norm, although, in terms of cells with phenotypes CD3+, CD5+, CD4+, CD16+ and index CD4+/CD8+ they were significantly lower than control values (Sokolenko \& Sokolenko, 2017a; Sokolenko et al., 2018). This could be a sign of the allostasis effect - a set of biological processes designed for dynamic stabilization under conditions of adaptation to environmental requirements, when, unlike homeostasis, parameters do not necessarily return to their initial levels, while remaining within the reference range values (Cool \& Zappetti, 2019). The examined students were in the second to fourth years of study, which means they had spent a considerable part of their time outside the area of enhanced radio-ecological control. Thus, the discovered effect at the level of the immune system can be characterized as an allostatic response.

During the additional emotional load (examination session period) a considerable share of the analyzed indicators shifted to their homeostatic limits, many of the examined had an immunoregulatory index CD4+/CD8+ beyond the lower limit, which was caused by a significant decrease in the level of functionally mature T lymphocyte with CD4+ phenotype (Sokolenko \& Sokolenko, 2017a; Sokolenko et al., 2018). This gave a reason to analyze the $\mathrm{CD} 4+/ \mathrm{CD} 8+$ ratio as a manifestation of allostatic load at the level of immune system integrative activity and to find out the relative risk of participation of related factors in its formation.

There are four main ways of forming allostatic load. The first one is to cause frequent repetitions of one stressor type for short periods of time when the body lacks time for adaptation. The second way is caused by the suppressed capacities of adaptation mechanisms, with each subsequent action of the stressor the reaction becomes less adequate. The third way of forming allostatic load is a prolonged stress reaction without recovery after the stressor cessation. A fourth way is to develop an inadequate response to a stress factor (McEwen, 2007). The revealed specifics of the parameters of immune-neuroendocrine status in the examined group can be considered as the consequences of the third way (long-term residence in the radiation-contaminated territory as a chronic stressor) and the second way (with certain characteristics: radiation-induced suppression of the adaptive potential with the signs of allostatic load under the influence of stress of a different nature: psycho-emotional).

Numerous mediators are involved in the development of adaptive processes in chronic stress and, accordingly, various biomarkers of allostatic load, among which primary (in particular, stress hormones), secondary - dysregulated metabolic, cardiovascular and immune parameters; and tertiary - clinical indicators can be distinguished (McEwen, 1998). In the group of examined students aged 18-24 year old who formed the experimental group, there were no clinical manifestations of maladaptation, respectively, we were searching for signs of primary and secondary markers of allostasis disturbance.

A recognized primary biomarker of allostatic loading is cortisol (Seeman et al., 1997). All examined students from the experimental group had an increased cortisol level (at the limit of homeostatic norm), then the indicator showed further increase during additional emotional load and exceeded $850 \mathrm{nmol} / \mathrm{L}$ (Sokolenko \& Sokolenko, 2015; Sokolenko \& Sokolenko, 2016).

An increase in the level of cortisol is observed in both acute and chronic stress exposure, depending not only on the main load, but also its interaction with other factors. Chronic stressors affect sensitivity to acute stressors (Sonnentag \& Fritz, 2006). Chronic cortisol production is neurotoxic to the sensitive parts of the brain and can lead to emotional and cognitive impairment throughout the life cycle (Lupien et al., 2009). Stress hormones, as primary mediators, cause primary stress reactions that disappear after the stressor's cessation. With prolonged stress reactions, they can lead to secondary dysfunction and even tertiary (illness or death) (McEwen, 2007).

There are facts which indicate a certain relationship of cortisol level and aging, although, the mechanism for its participation in age-related changes in immunity remains questionable (Larbi et al., 2008). It should be noted that an important factor in adverse age-related changes is the increased level of psycho-emotional stress, in particular in educational institutions (Seng, 2009). High school students, regardless of gender, are characterized by low levels of stress resistance due to the formation of internal, often unconscious psychological conflicts and a state of "latent anxiety" (Chystenko, 2013). Probably, the exam session for the students in the examined group was a factor in disclosure of hidden maladaptation phenomena caused by the previous prolonged radiation exposure.

Thus, a significant increase in the level of cortisol when combined with chronic (radiation) and short-term (increased emotional load) stress can be regarded as the primary marker of allostatic load in the experimental group. Clearly, the observed effect caused some reactions not only at the level of the immune system, but also in general for the immune-neuroendocrine complex. The calculation of the relative risk of cortisol participation in such reactions is irrelevant because all members of the experimental group showed cortisol increase over the upper limit of homeostatic norm. It is important to analyze the variational secondary changes and their degree of involvement in the formation of the immunoregulatory index decrease. In particular, a significant number of the examined had signs of metabolic syndrome, thyroid dysfunction and vegetative-vascular dystonia syndrome (Sokolenko, 2016a; Sokolenko \& Sokolenko, 2017b).

An important biomarker of allostatic loading is lipid metabolism (Seeman et al., 1997). During the additional psycho-emotional load caused by the examination session, out of 100 students from the territories of enhanced radio-ecological control, 62 persons reached the upper limit of norm in total cholesterol, mainly due to low density lipoprotein cholesterol (Sokolenko, 2016a; Sokolenko \& Sokolenko, 2017b). The calculation of relative and attributable risk showed a significant involve- 
ment of low density lipoprotein cholesterol in the formation of allostatic load signs at the level of the immunoregulatory index (Table 1).

Thyroid dysfunctions without clinical manifestations of thyroid pathology were considered as manifestations of secondary maladaptative reactions in some of the examined students. In particular, 48 people had signs of moderate hyperthyroidism, 21 - signs of moderate hypothyroidism. Previous studies have shown that individuals with signs of thyroid dysfunction had more pronounced differences of immune system parameters compared to control, especially at the level of T-cell immunity (Sokolenko \& Sokolenko, 2017a). The calculated relative risks for the subgroups of hyperthyroidism and hypothyroidism showed that in both cases their statistical significance is evident $(\mathrm{P}<0.05)$, the statistical significance of the differences of qualitative characteristics in the groups, although, in the state of hypothyroidism, the relative risk of going beyond the lower limit of immunoregulatory rate is 1.28 times higher than in the hyperthyroidism group.

Considering the peculiarities of correlation of stress influence biomarkers (Wiley et al., 2016), presence of vegetative-vascular dystonia syndrome in 50 people from the experimental group was a manifestation of total allostatic load at the level of neuroendocrine and cardiovascular systems. Previous studies have shown that in the group with signs of vegetative-vascular dystonia syndrome, the analyzed immune system indicators had the maximum significant differences from the indicators of control (in particular, in the relative number of functionally mature T lymphocytes with phenotypes CD3+ and CD4+, phagocytic index and phagocytic number of monocytes). Under conditions of additional psycho-emotional load, there were significant differences between the groups with and without the syndrome in terms of the CD4+/CD8+ immunoregulatory index (Sokolenko, 2016a).

The potential participation of vegetative-vascular dystonia syndrome in the formation of maladaptation reactions of the immune system was confirmed by the calculated relative risk of its participation in the decrease of the CD4+/CD8+ index, (the association of factors is confirmed by the analysis of $95 \%$ confidence interval and calculation of $\chi^{2}$ and attributable risk, Table 1).

Formation of the syndrome of vegetative-vascular dystonia, in turn, was apparently conditioned by both the features of the lipid profile and the thyroid status of the examined: the relative risk of development is significant with the signs of hyperthyroidism, hypothyroidism and with elevated level of low density lipoprotein cholesterol. The attributable risk in all cases exceeded 0.10 (Table 2)

In general, the analyzed factors show that the highest value of the relative risk of immunoregulatory index going beyond the lower limit was observed when the level of low density lipoprotein cholesterol was over the upper limit. The revealed features of the participation of the analyzed indicators of lipid profile and thyroid status in allostatic reactions of the immune system are logical, since metabolic processes play an important role in adaptation to environmental conditions (Somero et al., 2017). Metabolic parameters and specifics of lipid metabolism are, at the same time, significant biomarkers of aging (Fontana et al., 2010; Glei et al., 2011). In addition, the adaptive mechanisms that are implemented at the molecular level through metabolic processes form certain features of the morphofunctional organization of the organism and indicate a close relationship between biochemical parameters and parameters of endocrine status. Endocrine indicators are, in turn, highly dependent on current environmental factors and can be used to monitor human health (Bets, 2005).

Indeed, we have shown the variability of lipid metabolism in individuals from the experimental group depending on the thyroid status, the formation of thyroid-associated proatherogenic phenomena. Moreover, the involvement of thyroid status in lipid metabolism regulation was largely leveled off by additional emotional stress (Sokolenko \& Sokolenko, 2017b).

Thus, there were prerequisites for the calculation of RR for a set of factors. It turned out that the combination of hyperthyroidism, vegetativevascular dystonia syndrome and elevated level of low density lipoprotein cholesterol gave a 1.19 increase in the relative risk of the immunoregulatory index going beyond the lower limit compared to the individual influence of low density lipoprotein cholesterol, a 1.52 increase compared to the individual influence of vegetative-vascular dystonia syndrome, a 1.79 increase compared to the individual influence of hyperthyroidism. The combination of hypothyroidism, vegetativevascular dystonia syndrome and elevated level of low density lipoprotein cholesterol gave a 1.35 increase in the relative risk of immunoregulatory index decrease compared to the individual effect of low density lipoprotein cholesterol, 1.72 increase compared to the individual effect of vegetative-vascular dystonia syndrome, 1.59 increase compared to the individual effect of hypothyroidism.

Attributable risk in all cases exceeded 0.10. However, in the combination of hyperthyroidism, vegetative-vascular dystonia syndrome and elevated level of low density lipoprotein cholesterol, the etiological fraction value was less than with separately calculated elevated level of low density lipoprotein cholesterol; in the combination of hypothyroidism, vegetative-vascular dystonia syndrome and elevated level of low density lipoprotein cholesterol, the attributable risk is less than with the separately calculated elevated level of low density lipoprotein cholesterol and hyperthyroidism.

Thus, when several factors are combined, the value of the attributable risk of a given complex is, in certain cases, less than the attributable risk of the individual constituent components. This can be explained by the fact that the specified combination of several risk factors in a population may occur in fewer individuals than the presence of individual factors. The highest value of attributable risk was observed for the elevated level of low density lipoprotein cholesterol, due to the presence of this characteristic in a large number of examined students.

Reduction in the number of T cells with the CD4+ phenotype, accumulation of effector T cells with the CD8+ phenotype and, in general, inversion of the CD4+/CD8+ ratio are considered to be an important feature of the Immune Risk Phenotype (IRP). The Immune Risk Phenotype, in turn, is a manifestation of the body's immune aging (Wikby et al., 2006; Larbi et al., 2008; Ventura et al., 2017). Quantitative changes of T lymphocyte with CD4+ and CD8+ phenotypes are especially pronounced in peripheral blood flow (Lugli et al., 2007; Pinti et al., 2016).

Immune aging, or immunosenescence, is a term that characterizes age-related decline in immune competence and increases susceptibility to disease (Gomez et al., 2005; Pawelec et al., 2005). This phenomenon is a complex inevitable process, typical for human life and characterized by the accumulation in the body of memory cells and effectors (as a result of previous antigenic stimulation), immune cells with stress-modified structures or functions, the development of chronic inflammation and modification of the immune response, conditioned by oxidative stress (Campisi \& di Fagagna, 2007; Ventura et al., 2017).

Immunosenescence arises from the complex of numerous and multiple changes in the process of hematopoiesis, the development and differentiation of immune cells, their functions. Especially susceptible to this process is the adaptive immune system, which is caused by agerelated thymus involution and prolonged antigenic stimulation of mature peripheral $\mathrm{T}$ cells, which often exceeds the adaptive potential. This leads to congestion of innate immunity, the accumulation of molecular and cellular defects at different levels of the immune response and the development of the effect of aging. Chronic antigenic loading at a young age is especially pressing, and physiological processes of aging of the T-cell immune system become a significant factor of long term survival (Larbi et al., 2008; Pinti et al., 2016). Possibly, a similar mechanism was applied to the relative immunosuppression detected in persons from the experimental group, the role of "antigenic load" for them was played by the prolonged effect of small doses of radiation.

In general, the immune response strategy is characterized by welldefined age-related features (Klimova et al., 2018). Characteristics of allostatic load markers and prerequisites for the development of immunosenescence in certain cohorts of the population are important not only in medical practice but also for a deeper understanding of the concept of biological age. Age is a multifactorial indicator of ontogenesis. There are four types of age: chronological, biological, psychological and social (Plakuev et al., 2011). Assessment of the biological age of a person is aimed mainly at quantitative assessment of the organism based on the analysis of the stages of its aging. That is, such assessment involves biological (gerontological) characterization rather than nosological diag- 
nosis, taking into account the classification of diseases or concepts of their development (Voitenko, 1987; Voitenko et al., 1989). However, prenosological diagnostics is important in disease prevention and detection of high-risk groups at a certain stage of ontogenesis. The specifics of many aging processes are their mismatch between the chronological and biological age of a person, which must be taken into account when assessing the degree of viability and biological capacity of the human body (Krikshtopaitis, 1993).

The development of age characteristics is controlled at the genetic level and depends on the abiotic, biotic and social factors of the environment (Hofer \& Piccinin, 2010). Failure to adapt effectively to new or extreme social and environmental conditions leads to chronic stress and, as a consequence, pathological aging (Makovsky, 2006).

Thus, the exceeding of the normal limits of the CD4+/CD8+ ratio in conditions of additional stress observed in the experimental group can be considered as an important prognostic marker of not only allostatic load, but also of premature age-related destructive processes.

Previous studies of the relations between immune risk phenotype formation and various psychosocial factors have revealed associations only at the level of persistent cytomegalovirus infection in very old individuals (Wikby et al., 2005). In our case there was an imposition of emotional load on the adaptation-maladaptation processes caused by the previous chronic radiation stress.

In addition to the immunoregulatory index and its components, there are other indicators of the immune risk phenotype that characterize the process of immunosenescence. Innate immunity has been considered resistant to aging processes for a long time, and now both structural and functional age-related changes have been identified for its components (Pinti et al., 2016). The number of neutrophils in seniors remains stable, however, both receptor and metabolic capacities (at the level of oxidative processes) deteriorate, chemotactic and phagocytic activity decreases, depending on certain additional factors (Alonso-Fernández et al., 2008; Brubaker et al., 2013; Wiley et al., 2016). The number of monocytes in peripheral blood does not change significantly with age, age-related changes are mainly related to macrophage activity, however, there is evidence of phagocytosis inhibition in monocytes and the production of reactive oxygen (Plowden et al., 2004; Hearps et al., 2012; Metcalf et al., 2015). In general, when exposed to extreme exogenous factors, phagocytic activity is indicated among the sensitive factors of innate immunity (Skivka et al., 2015a; Boieva et al., 2018). The age-related changes in the number and function of NK cells, which are considered to be short-lived effector cells, are quite controversial. There are publications on the decrease, increase or stable number of lymphocytes with the CD16+ phenotype in seniors (Le Garff-Tavernier et al., 2010; Gayoso et al., 2011).

In our studies, the people from the experimental group showed a significantly increased relative and absolute number of stab neutrophils and segmented neutrophils compared to the control, although their phagocytic activity (as well as phagocytic activity of monocyte) was lower than the control values. A significantly lower level of killer cells with the CD16+ phenotype was observed. During the examination session, relative immunosuppression at the level of phagocytic activity of monocytes and neutrophils, as well as the number of NK cells increased. However, the indicators did not go beyond the homeostatic norm (Sokolenko \& Sokolenko, 2017a; Sokolenko et al., 2018), so they were not attributed to significant markers of allostatic load when combined with radiation-induced and emotional stress.

According to the literature, at the level of humoral specific immunity in seniors there is a decrease in the level of IgM, which is a sign of young B cells' transformation into memory cells (Weksler \& Szabo, 2000). In parallel, an increase in IgG and IgA levels were observed (Paganelli et al., 1992). In our studies, increased level of serum IgG compared to controls was considered to be a compensatory effect of reducing $\mathrm{T}$ cell immunity rather than a sign of immune aging. The indicator did not go beyond the norm, and it significantly decreased with additional psycho-emotional load (Sokolenko et al., 2018).

An important factor in the immune system aging is the accumulation of reactive oxygen species (ROS) in the body and the development of free radical processes. This, in turn, leads to the damage of important cellular components (in particular, biological membranes, structural and enzymatic proteins, etc.), impaired apoptosis (Ginaldi et al., 2004; Liochev, 2013). Activation of oxidative phenomena that accompanies the processes of accelerated aging in artificially stimulated hyperthyroidism (Bozhkov \& Nikitchenko, 2014), the accumulation of free radicals with age (in particular, formed during lipid metabolism) is a consequence of the destructive influence of the extreme environment factors (Haigis \& Yankner, 2010). The free radical theory that describes macromolecular damage in enhancing the reactive oxygen species generation was dominant for a long time in explaining the causes of aging, but numerous contradictory studies indicate the complexity of the mechanisms of process realization (Lapointe \& Hekimi, 2010). At the same time, an increase of oxidation processes is a typical consequence of radiation (Ahmad et al., 2016).

Activation of stress-protective mechanisms (in particular, removal of free radicals, increasing of endogenous antioxidants), reparative processes, elimination of damaged cells by immune factors are the main mechanisms of adaptive response realization and a phenomenon of radiation hormesis to low-dose irradiation. However, it is still unknown how the greater part of the effects observed in vitro conditions work in vivo. Accordingly, obtaining and analyzing more data regarding the oxidative effects of low-dose irradiation remains relevant (Mattsson \& Nilsson, 2015; Nenoi et al., 2015; Vaiserman et al., 2019).

We have shown that the examined students from the experimental group experienced an intensification of oxidation processes (in particular, at the level of the oxidative stress index), especially pronounced under conditions of additional emotional load. The redox homeostasis imbalance has been associated with the signs of thyroid dysfunction (especially with a state of hypothyroidism) and proatherogenic changes in the lipid profile (Sokolenko \& Sokolenko, 2019) and it is reflected in immune system indicators (Sokolenko et al., 2018). However, neither the level of malondialdehyde nor the level of analyzed antioxidant factors went beyond the homeostatic norm, so they were not indicated as significant bioindicators of the allostatic load of the examined students, the calculation of the relative risk of maladaptive processes was not performed for them.

Genetic factors are important modulators of human adaptive capacity and sensitivity to chronic stress (Belsky et al., 2009; Meaney, 2010; Belsky \& Pluess, 2013). At the same time, they control the complex development of the immune system and its individual components, the balance of mediators of integrative activity, in particular, at the level of inflammatory factors. Accordingly, genetic determinants define, to a considerable extent, age-related changes in the immune response (Franceschi et al., 2007; Hsu et al., 2007).

In our studies, there were some associative relationships between the immune system and the phenotype of erythrocyte (AB0, Rhesus) and serum (haptoglobin Hp system) genetic systems, although they were revealed only under conditions of psycho-emotional loading and did not play a significant role in determining overrunning of the limits of homeostatic norm (Sokolenko, 2016b).

When characterizing stressful conditions, it is important to consider the gender of the examined and the individual gender characteristics acquired over the course of life. In addition, the duration, frequency of stress effects and their particularities are assessed, in particular whether the object had encountered such a stressor before (Juster \& Lupien, 2012; Lupien et al., 2015). Neither prolonged radiation exposure nor examination session can be considered as "new" stressors for the examined. However, students from radiation-contaminated territories did not show gender variability of the analyzed indicators either in the absence or presence of additional psycho-emotional load (Sokolenko \& Sokolenko, 2017c). According to the findings, males are more sensitive to stress than females in the follicular stage of the menstrual cycle. However, most researches show that gender variability of $\mathrm{AL}$ formation is manifested only in seniors. The subtle physiological features of adaptive reactions are almost not manifested in young persons of both sexes (Juster \& Lupien, 2012), which is consistent with our results.

Analyzing the reasons for premature aging of the immune system in the experimental group, one should not forget that the group was formed by young people aged 18-24. When determining the biomarkers of allostatic loading, it is recommended to consider the age factor (Kar- 
lamangla et al., 2006; Juster et al., 2010; Cool \& Zappetti, 2019). This is logical because the specifics of age-related induction of genes of stress response are observed at different levels of vertebrate organization (Yankner et al., 2008). Teenagers and people of advanced age are especially vulnerable to stress. Hormonal rearrangements of teenagers against the background of stressful effects lead to the formation of socalled "potentiation/incubation effects", which may appear in later life ("manifestation effects") (Lupien et al., 2009).

It should be taken into consideration that individuals in the study group were exposed to small doses of radiation not only during their teens, but also from prenatal development or the first years of life. Prenatal and early postnatal factors play an important role in subsequent adaptive processes (Pluess \& Belsky, 2011). In general, two reactions are distinguished in the formation of adaptation: the reaction of regulation (occurs in response to a short-acting factor) and development (occurring during human growth and development to prevailing environmental conditions; they are usually irreversible) (Moran, 2018). Revealed signs of allostasis in the experimental group can be regarded as a display of the developmental response and the effect of allostatic load during the examination session - as its negative consequence due to the slow and weak regulation response.

Thus, living in radiation-contaminated territories in the pubertal period could significantly affect the specifics of the adaptive response formation and allostatic load formation.

In epidemiological studies related to the radiation exposure of the population, certain results are considered to be consequences of concomitant factors and certain biased views (Shibamoto \& Nakamura, 2018). Some authors suggest that the risk of harm to the body from chronic small-dose irradiation (from 0.001 to $0.30 \mathrm{~Gy}$ ) caused by the contamination of the territory due to the Chornobyl accident is hyperbolized, and further, that the fear of possible consequences, creates more health problems, than the radiation itself. The confirmatory argument is the information on the stimulating effects of small doses, radiation-induced stimulation of adaptive and reparative processes, which reduces the risk of cancer. Thus, the idea of radiation hormesis is supported (Cuttler, 2007). However, the author does not take into account that the stimulating effect of low doses was observed mainly in vitro. For significant irradiated population cohorts, signs of radiation hormesis remain questionable (Richardson, 2009), as confirmed by our findings.

It should be noted that the signs of allostasis and allostatic load found in the study group are, at the same time, biomarkers of premature aging. There is no doubt that individuals of the same age can show different speeds of aging (Xia et al., 2017). However, the formation of such traits in a significant cohort of young people is a matter of concern. Allostatic loading demonstrates not only an inadequate response to stress, but also impaired post-stress recovery processes (Cool \& Zappetti, 2019). Under such conditions, the combination of various important biological mechanisms of aging further increases susceptibility to certain chronic diseases and the inhibition of individual functions. The problem of finding remedies for the "driving factors" of premature age-related changes in risk groups continues to be the absence in clinical practice of approved or recognized biomarkers of aging, their search and further analysis remains a pressing issue (Justice et al., 2018). In this sense, analysis of the CD4+/CD8+ dynamics, as a simultaneous marker of allostatic load and premature aging of the immune system has an important prognostic value. Traditionally, in the characterization of immune aging, considerable attention is given to SASP (senescence-associated secretory phenotype), among them an important role is played by soluble factors of the immune system, in particular, inflammatory factors (Wajapeyee et al., 2008; Leonardi et al., 2018; McHugh \& Gil, 2018). Their accumulation is a consequence of an imbalance between inflammatory and anti-inflammatory mechanisms, leading to activation of inflammatory processes (Franceschi et al., 2007; Cevenini et al., 2013; Minciullo et al., 2016).

Immunosenescence can be asymptomatic for a long time (Larbi et al., 2008). Thereafter, an analysis of the factors that contribute to the suppression of the immunoregulatory index makes it possible to identify disguised maladaptation processes and premature age changes in young people subject to prolonged exogenous influences. Thus, the data obtained demonstrate some manifestations of maladaptation of the im- mune-neuroendocrine complex in individuals aged 18-24 years who have sustained prolonged exposure to small doses of ionizing radiation. These manifestations, with additional exogenous effects of stressful nature, can lead to the formation of signs of allostatic loading, a potential pattern of its development is shown in Figure.

The understanding of the molecular mechanisms of occurrence of LDIR- and LDRIR-induced pathologies will be facilitated by the assessment of bio-negative effects using radiosensitive animal populations. However, long-term studies which take into account numerous factors, remain important for predicting the long-term effects of chronic radiation exposure (Møller \& Mousseau, 2016; Tang et al., 2016).

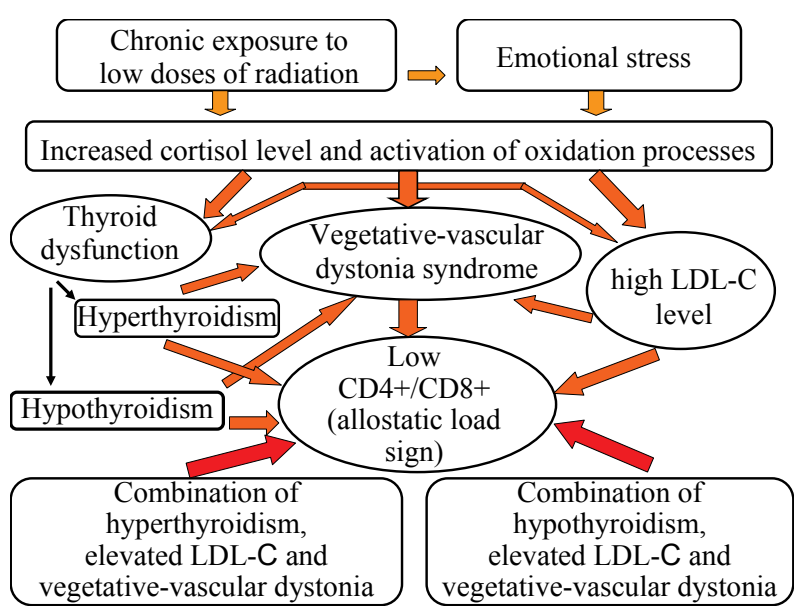

Fig. Scheme of allostatic load development (at the level of the CD4+/CD8+ immunoregulatory index) in persons aged 18-24 years, who underwent prolonged exposure to small doses of radiation

\section{Conclusions}

In individuals aged 18-24 years who lived in the territories of enhanced radio-ecological control from birth to adulthood, signs of allostasis of individual parameters of the immune-neuroendocrine complex were formed. In conditions of additional emotional stress it leads to the immunoregulatory index going beyond the limits of homeostatic norm, which can be considered an important secondary biomarker of allostatic load and premature age-related changes in the immune system. Indirect biomarkers of allostatic load are involved in the formation of this condition: the signs of vegetative-vascular dystonia syndrome, hyperthyroidism, hypothyroidism, hypercholesterolemia (due to the low density lipoprotein cholesterol fraction). This is confirmed by the calculated relative and attributable risks of the participation of these factors in the reduction of the CD4+/CD8+ index. With the complex effects of mediated biomarkers, the relative risk of allostatic loading (at the level of suppression of the immunoregulatory index) increases.

\section{References}

Ahmad, I. M., Temme, J. B., Abdalla, M. Y., \& Zimmerman, M. C. (2016). Redox status in workers occupationally exposed to long-term low levels of ionizing radiation: A pilot study. Redox Report, 21(3), 139-145.

Akhaladze, N. G. (2016). Hirosima i Nagasaki, Chernobyil i Fukusima. Vliyanie otdalennyih effektov ioniziruyuschego oblucheniya na temp stareniya i zhiznesposobnost cheloveka (obzor literaturyi) [Hiroshima and Nagasaki, Chernobyl and Fukushima. Remote effects of exposure to ionizing radiation on the rate of human aging and viability (review of literature)]. Problems of Aging and Development, 25(3), 369-379 (in Russian).

Alonso-Fernández, P., Puerto, M., Maté, I., Ribera, J. M., \& De La Fuente, M. (2008). Neutrophils of centenarians show function levels similar to those of young adults. Journal of the American Geriatrics Society, 56(12), 2244-2251.

Baldwin, J., \& Grantham, V. (2015). Radiation hormesis: Historical and current perspectives. Journal of Nuclear Medicine Technology, 43(4), 242-246.

Belsky, J., \& Pluess, M. (2009). Beyond diathesis-stress: Differential susceptibility to environmental influences. Psychological Bulletin, 135, 885-908. 
Belsky, J., \& Pluess, M. (2013). Beyond risk, resilience, and dysregulation: Phenotypic plasticity and human development. Development and Psychopathology, 25, 1243-1261.

Belsky, J., Jonassaint, C., Pluess, M., Stanton, M., Brummett, B., \& Williams, R. (2009). Vulnerability genes or plasticity genes? Molecular Psychiatry, 14, 746-754.

Bernal, A. J., Dolinoy, D. C., Huang, D., Skaar, D. A., Weinhouse, C., \& Jirtle, R. L. (2013). Adaptive radiation-induced epigenetic alterations mitigated by antioxidants. The FASEB Journal, 27(2), 665-671.

Bets, L. V. (2005). Ecological variability of hormonal concentrations in modern humans. Journal of Physiological Anthropology and Applied Human Science, 24(4), 451-457.

Bilokur, D. (2018). Pokaznyky nespetsyfichnoho antyinfektsiinoho zakhystu u osib z terytorii posylenoho radioekolohichnoho kontroliu Sumskoi oblasti [Indicators of nonspecific anti-infectious protection of individuals in the territories of intensified radioecological control of the Sumy Region]. Lesya Ukrainka Eastern European National University Scientific Bulletin, Series Biological Sciences, 377, 86-91 (in Ukrainian).

Boieva, S. S., Raksha-Sliusareva, O. A., \& Sliusarev, O. A. (2018). Indicators of phagocytic activity, autosensibilization and purine metabolism in patients with pneumoconiosis. Zaporozhye Medical Journal, 4, 496-502.

Bozhkov, A. I., \& Nikitchenko, Y. V. (2014). Thermogenesis and longevity in mammals. Thyroxin model of accelerated aging. Experimental Gerontology, 60, 173-182.

Brubaker, A. L., Rendon, J. L., Ramirez, L., Choudhry, M. A., \& Kovacs, E. J. (2013). Reduced neutrophil chemotaxis and infiltration contributes to delayed resolution of cutaneous wound infection with advanced age. The Journal of Immunology, 190(4), 1746-1757.

Calabrese, E. J., \& O'Connor, M. K. (2014). Estimating risk of low radiation doses A critical review of the BEIR VII Report and its use of the linear no-threshold (LNT) hypothesis. Radiation Research, 182(5), 463-474.

Campisi, J., \& di Fagagna, F. D. A. (2007). Cellular senescence: When bad things happen to good cells. Nature Reviews Molecular Cell Biology, 8(9), 729-740.

Cevenini, E., Monti, D., \& Franceschi, C. (2013). Inflamm-ageing. Current Opinion in Clinical Nutrition and Metabolic Care, 16(1), 14-20.

Chen, W. L., Luan, Y. C., Shieh, M. C., Chen, S. T., Kung, H. T., Soong, K. L., Yeh, Y. C., Chou, T. S., Mong, S. H., Wu, J. T., Sun, C. P., Deng, W. P., Wu, M. F., \& Shen, M. L. (2007). Effects of cobalt-60 exposure on health of Taiwan residents suggest new approach needed in radiation protection. Dose-Response, $5(1), 63-75$.

Chystenko, I. H. (2013). Osoblyvosti adaptatsii uchniv riznykh vikovykh hrup do stresovykh chynnykiv [Adaptation peculiarities of students from different age groups to stressors]. Bulletin of the Chernihiv National Pedagogical University, Psychological Science Series, 114, 204-207 (in Ukrainian).

Cool, J., \& Zappetti, D. (2019). The physiology of stress. In: Medical Student Well-Being. Springer, Cham. Pp. 1-15.

Cuttler, J. M. (2007). Health effects of low level radiation: When will we acknowledge the reality? Dose-Response, 5(4), 292-298.

Davis, F. G., Krestinina, L. Y., Preston, D., Epifanova, S., Degteva, M., \& Akleyev, A. V. (2015). Solid cancer incidence in the Techa River incidence cohort: 1956-2007. Radiation Research, 184(1), 56-65.

Dobzhansky, T. (1968). On some fundamental concepts of Darwinian biology. In: Evolutionary biology. Springer, Boston. Pp. 1-34.

Esteller, M., \& Herman, J. G. (2002). Cancer as an epigenetic disease: DNA methylation and chromatin alterations in human tumours. The Journal of Pathology, 196(1), 1-7.

Fontana, L., Partridge, L., \& Longo, V. D. (2010). Extending healthy life span from yeast to humans. Science, 328(5976), 321-326.

Franceschi, C., Capri, M., Monti, D., Giunta, S., Olivieri, F., Sevini, F., Panourgia, M. P., Invidia, L., Celani, L., Scurti, M., Cevenini, E., Castellani, G. C., \& Salvioli, S. (2007). Inflammaging and anti-inflammaging: A systemic perspective on aging and longevity emerged from studies in humans. Mechanisms of Ageing and Development, 128(1), 92-105.

Galván, I., Bonisoli-Alquati, A., Jenkinson, S., Ghanem, G., Wakamatsu, K., Mousseau, T. A., \& Møller, A. P. (2014). Chronic exposure to low-dose radiation at Chemobyl favours adaptation to oxidative stress in birds. Functional Ecology, 28(6), 1387-1403.

Gayoso, I., Sanchez-Correa, B., Campos, C., Alonso, C., Pera, A., Casado, J. G., Morgado, S., Tarazona, R., \& Solana, R. (2011). Immunosenescence of human natural killer cells. Journal of Innate Immunity, 3(4), 337-343.

Ginaldi, L., De Martinis, M., Monti, D., \& Franceschi, C. (2004). The immune system in the elderly: Activation-induced and damage-induced apoptosis. Immunologic Research, 30(1), 81-94.

Glei, D. A., Goldman, N., Lin, Y. H., \& Weinstein, M. (2011). Age-related changes in biomarkers: Longitudinal data from a population-based sample. Research on Aging, 33(3), 312-326.

Gomez, C. R., Boehmer, E. D., \& Kovacs, E. J. (2005). The aging innate immune system. Current Opinion in Immunology, 17(5), 457-462.
Gourabi, H., \& Mozdarani, H. (1998). A cytokinesis-blocked micronucleus study of the radioadaptive response of lymphocytes of individuals occupationally exposed to chronic doses of radiation. Mutagenesis, 13(5), 475-480.

Grjibovski, A. M. (2008). Analiz nominalnyih dannyih (nezavisimyie nablyudeniya) [Analysis of nominal data (independent observations)]. Human Ecology, 6, 58-68 (in Russian).

Haigis, M. C., \& Yankner, B. A. (2010). The aging stress response. Molecular Cell, 40(2), 333-344.

Hayflick, L. (2007). Biological aging is no longer an unsolved problem. Annals of the New York Academy of Sciences, 1100(1), 1-13.

Hearps, A. C., Martin, G. E., Angelovich, T. A., Cheng, W. J., Maisa, A., Landay, A. L., Jaworowski, A., \& Crowe, S. M. (2012). Aging is associated with chronic innate immune activation and dysregulation of monocyte phenotype and function. Aging Cell, 11(5), 867-875.

Hernández, L., Terradas, M., Camps, J., Martín, M., Tusell, L., \& Genescà, A. (2015). Aging and radiation: Bad companions. Aging Cell, 14(2), 153-161.

Hofer, S. M., \& Piccinin, A. M. (2010). Toward an integrative science of life-span development and aging. Journals of Gerontology Series B: Psychological Sciences and Social Sciences, 65(3), 269-278.

Hsu, H. C., Lu, L., Yi, N., Van Zant, G., Williams, R. W., \& Mountz, J. D. (2007). Quantitative trait locus (QTL) mapping in aging systems. In: Biological aging. Humana Press. Pp. 321-348.

Juster, R.-P., \& Lupien, S. J. (2012). Chronic stress and allostatic load. In: Handbook of clinical gender medicine. Karger Publishers. Pp. 70-81.

Juster, R.-P., McEwen, B. S., \& Lupien, S. J. (2010). Allostatic load biomarkers of chronic stress and impact on health and cognition. Neuroscience and Biobehavioral Reviews, 35(1), 2-16.

Justice, J. N., Ferrucci, L., Newman, A. B., Aroda, V. R., Bahnson, J. L., Divers, J., Espeland, M. A., Marcovina, S., Pollak, M. N., Kritchevsky, S. B., Barzilai, N., \& Kuchel, G. A. (2018). A framework for selection of blood-based biomarkers for geroscience-guided clinical trials: report from the TAME Biomarkers Workgroup. GeroScience, 40(5-6), 419-436.

Karlamangla, A. S., Singer, B. H., \& Seeman, T. E. (2006). Reduction in allostatic load in older adults is associated with lower all-cause mortality risk: MacArthur studies of successful aging. Psychosomatic Medicine, 68(3), 500-507.

Kirkwood, T. B., \& Shanley, D. P. (2010). The connections between general and reproductive senescence and the evolutionary basis of menopause. Annals of the New York Academy of Sciences, 1204(1), 21-29.

Klimova, E. M., Bozhkov, A. I., Kovalenko, T. I., Minukhin, V. V., \& Belozerov, I. V. (2018). Young and old animals use different strategies for forming an immune response to infectious agents (Pseudomonas aeruginosa and Escherichia coli). Advances in Gerontology, 8(4), 284-291.

Korenev, M. M., Plekhova, O. I., Kalmykova, N. V., Kashina, V. L., \& Borisko, G. O. (2009). Osoblyvosti lipidnoho spektru krovi u nashchadkiv likvidatoriv avariyi na ChAES [Some features of blood lipid spectrum in descendants of liquidators of the consequences of the Chernobyl accident]. Sovremennaja Pediatrija, 25, 56-58 (in Ukrainian).

Krikshtopaitis, M. Y. (1993). Problemyi fiziologicheskih osnov preduprezhdeniya rannego stareniya cheloveka [Problem of physiological fundamentals of the prevention of premature aging in humans]. Human Physiology, 16(5), 161167 (in Russian).

Krivoschekov, S. G., \& Mozolevskaya, N. V. (2007). Physiological mechanisms of adaptation and disadaptation in the North. Alaska Medicine, 49(2), 32-34.

Lapointe, J., \& Hekimi, S. (2010). When a theory of aging ages badly. Cellular and Molecular Life Sciences, 67(1), 1-8.

Larbi, A., Franceschi, C., Mazzatti, D., Solana, R., Wikby, A., \& Pawelec, G. (2008). Aging of the immune system as a prognostic factor for human longevity. Physiology, 23(2), 64-74.

Le Garff-Tavemier, M., Béziat, V., Decocq, J., Siguret, V., Gandjbakhch, F., Pautas, E., Debré, P., Merle-Beral, H., \& Vieillard, V. (2010). Human NK cells display major phenotypic and functional changes over the life span. Aging Cell, 9(4), 527-535.

Leonardi, G. C., Accardi, G., Monastero, R., Nicoletti, F., \& Libra, M. (2018). Ageing: From inflammation to cancer. Immunity and Ageing, 15(1), 1.

Leuraud, K., Richardson, D. B., Cardis, E., Daniels, R. D., Gillies, M., O’Hagan, J. A., Hamra, G. B., Haylock, R., Laurier, D., Moissonnier, M., SchubauerBerigan, M. K., Thierry-Chef, I., \& Kesminiene, A. (2015). Ionising radiation and risk of death from leukaemia and lymphoma in radiation-monitored workers (INWORKS): An international cohort study. The Lancet Haematology, 2(7), e276-e281.

Liochev, S. I. (2013). Reactive oxygen species and the free radical theory of aging. Free Radical Biology and Medicine, 60, 1-4.

López-Otín, C., Blasco, M. A., Partridge, L., Serrano, M., \& Kroemer, G. (2013). The hallmarks of aging. Cell, 153(6), 1194-1217.

Lugli, E., Pinti, M., Nasi, M., Troiano, L., Ferraresi, R., Mussi, C., Salvioli, G., Patsekin, V., Robinson, J. P., Durante, C., Cocchi, M., \& Cossarizza, A. (2007). Subject classification obtained by cluster analysis and principal com- 
ponent analysis applied to flow cytometric data. Cytometry Part A: The Journal of the International Society for Analytical Cytology, 71(5), 334-344.

Lupien, S. J., McEwen, B. S., Gunnar, M. R., \& Heim, C. (2009). Effects of stress throughout the lifespan on the brain, behaviour and cognition. Nature Reviews Neuroscience, 10(6), 434445.

Lupien, S. J., Ouellet-Morin, I., Hupbach, A., Tu, M. T., Buss, C., Walker, D., Pruessner, J. C., \& McEwen, B. S. (2015). Beyond the stress concept: Allostatic load - A developmental biological and cognitive perspective. Developmenta Psychopathology. Vol. 2: Developmental Neuroscience. Pp. 578-628.

Luz, C., Dornelles, F., Preissler, T., Collaziol, D., da Cruz, I. M., \& Bauer, M. E. (2003). Impact of psychological and endocrine factors on cytokine production of healthy elderly people. Mechanisms of Ageing and Development 124(8-9), 887-895

Makovsky, R. D. (2006). Zdorove naseleniya i okruzhayuschaya prirodnaya sreda regiona [Population health and natural environment of the region]. Human Ecology, 12, 9-11 (in Russian).

Mattsson, S., \& Nilsson, M. (2015). On the estimation of radiation-induced cancer risks from very low doses of radiation and how to communicate these risks. Radiation Protection Dosimetry, 165(1-4), 17-21.

McEwen, B. S. (1998). Protective and damaging effects of stress mediators. New England Journal of Medicine, 338(3), 171-179.

McEwen, B. S. (2007). Physiology and neurobiology of stress and adaptation: Central role of the brain. Physiological Reviews, 87(3), 873-904.

McEwen, B. S., \& Stellar, E. (1993). Stress and the individual: Mechanisms leading to disease. Archives of Internal Medicine, 153(18), 2093-2101.

McHugh, D., \& Gil, J. (2018). Senescence and aging: Causes, consequences, and therapeutic avenues. The Journal of Cell Biology, 217(1), 65-77.

Meaney, M. J. (2010). Epigenetics and the biological definition of gene x environment interactions. Child Development, 81, 41-79.

Metcalf, T. U., Cubas, R. A., Ghneim, K., Cartwright, M. J., Grevenynghe, J. V., Richner, J. M., Olagnier, D. P., Wilkinson, P. A., Cameron, M. J., Park, B. S., Hiscott, J. B., Diamond, M. S., Wertheimer, A. M., Nikolich-Zugich, J., \& Haddad, E. K. (2015). Global analyses revealed age-related alterations in innate immune responses after stimulation of pathogen recognition receptors. Aging Cell, 14(3), 421-432

Minchenko, J. M., Dyagil, I. S., Dmytrenko, O. O., Dmytrenko, I. V., Shlaykhtychenko, T. Y., Gavrylenko, T. I., Billi, D. O., \& Bebeshko, V. G. (2013) Znachennia henetychnykh markeriv radiochutlyvosti i radiorezystentnosti v formuvanni onkohematolohichnoi ta sertsevo-sudynnoi patolohii u oprominenykh pislia Chomobylskoi avarii [Role of radiosensitivity and radioresistance genetic markers in hematological and cardiovascular disease in persons exposed after the Chornobyl accident]. Problems of Radiation Medicine and Radiobiology, (18), 220-231 (in Ukrainian).

Minciullo, P. L., Catalano, A., Mandraffino, G., Casciaro, M., Crucitti, A., Maltese, G., Morabito, N., Lasco, A., Gangemi, S., \& Basile, G. (2016). Inflammaging and anti-inflammaging: The role of cytokines in extreme longevity. Archivum Immunologiae et Therapiae Experimentalis, 64(2), 111-126.

Møller, A. P., \& Mousseau, T. A. (2016). Are organisms adapting to ionizing radiation at Chernobyl? Trends in Ecology and Evolution, 31(4), 281-289.

Moran, E. (2018). Human adaptability: An introduction to ecological anthropology. Routledge.

Nenoi, M., Wang, B., \& Vares, G. (2015). In vivo radioadaptive response: A review of studies relevant to radiation-induced cancer risk. Human and Experimental Toxicology, 34(3), 272-283.

Nylund, R., Lemola, E., Hartwig, S., Lehr, S., Acheva, A., Jahns, J., Hildebrandt, G., \& Lindholm, C. (2014). Profiling of low molecular weight proteins in plasma from locally irradiated individuals. Journal of Radiation Research, 55(4), 674-682.

Olivieri, G., Bodycote, J., \& Wolff, S. (1984). Adaptive response of human lymphocytes to low concentrations of radioactive thymidine. Science, 223(4636), 594-597.

Orgiazzi, J. (2015). Radiation-related health effects of major nuclear events. La Revue du Praticien, 65(1), 93-94

Ostan, R., Bucci, L., Capri, M., Salvioli, S., Scurti, M., Pini, E., Monti, D., \& Franceschi, C. (2008). Immunosenescence and immunogenetics of human longevity. Neuroimmunomodulation, 15(4-6), 224-240.

Paganelli, R., Quinti, I., Fagiolo, U., Cossarizza, A., Ortolani, C., Guerra, E., Sansoni, P., Pucillo, L. P., Scala, E., Cozzi, E., Bertollo, L., Monti, D., \& Franceschi, C. (1992). Changes in circulating B cells and immunoglobulin classes and subclasses in a healthy aged population. Clinical and Experimental Immunology, 90(2), 351-354.

Pastel, R. H. (2002). Radiophobia: Long-term psychological consequences of Chernobyl. Military Medicine, 167(suppl. 1), 134-136.

Pawelec, G., Akbar, A., Caruso, C., Solana, R., Grubeck-Loebenstein, B., \& Wikby, A. (2005). Human immunosenescence: Is it infectious? Immunological Reviews, 205(1), 257-268.

Pinti, M., Appay, V., Campisi, J., Frasca, D., Fülöp, T., Sauce, D., Larbi, A. Weinberger, B., \& Cossarizza, A. (2016). Aging of the immune system: Fo- cus on inflammation and vaccination. European Journal of Immunology, 46(10), 2286-2301

Plakuev, A. N., Yuryeva, M. Y., \& Yuryev, Y. (2011). Sovremennyie kontseptsii stareniya i otsenka biologicheskogo vozrasta cheloveka [Modern concepts of ageing and assessment of human biological age]. Human Ecology, 4, 17-25 (in Russian).

Plowden, J., Renshaw-Hoelscher, M., Engleman, C., Katz, J., \& Sambhara, S. (2004). Innate immunity in aging: Impact on macrophage function. Aging Cell, 3(4), 161-167.

Pluess, M., \& Belsky, J. (2011). Prenatal programming of postnatal plasticity? Development and Psychopathology, 23, 29-38.

Rajah, M. N., Bastianetto, S., Bromley-Brits, K., Cools, R., D’Esposito, M., Grady, C. L., Poirier, J., Quirion, R., Raz, N., Rogaeva, E., Song, W., \& Pruessner, J. (2009). Biological changes associated with healthy versus pathological aging: A symposium review. Ageing Research Reviews, 8(2), 140-146.

Rando, T. A., \& Chang, H. Y. (2012). Aging, rejuvenation, and epigenetic reprogramming: Resetting the aging clock. Cell, 148, 46-57.

Richardson, R. B. (2009). Ionizing radiation and aging: Rejuvenating an old idea. Aging, 1(11), 887-902.

Rithidech, K. N., \& Scott, B. R. (2008). Evidence for radiation hormesis after in vitro exposure of human lymphocytes to low doses of ionizing radiation. Dose-Response, 6(3), 252-271.

Roff, D. A. (2012). Evolutionary quantitative genetics. Springer Science \& Business Media.

Rossnerova, A., Honkova, K., Pavlikova, J., Skalicka, Z. F., Havrankova, R., Solansky, I., Rossner, P., Sram, R. J., \& Zölzer, F. (2016). Mapping the facfors affecting the frequency and types of micronuclei in an elderly population from Southern Bohemia. Mutation Research/Fundamental and Molecular Mechanisms of Mutagenesis, 793, 32-40.

Rossnerova, A., Pokorna, M., Svecova, V., Sram, R. J., Topinka, J., Zölzer, F., \& Rossner, P. (2017). Adaptation of the human population to the environment: Current knowledge, clues from Czech cytogenetic and "omics" biomonitoring studies and possible mechanisms. Mutation Research/Reviews in Mutation Research, 773, 188-203.

Sacks, B., Meyerson, G., \& Siegel, J. A. (2016). Epidemiology without biology: False paradigms, unfounded assumptions, and specious statistics in radiation science (with commentaries by Inge Schmitz-Feuerhake and Christopher Busby and a reply by the authors). Biological Theory, 11(2), 69-101.

Seeman, T. E., Singer, B. H., Rowe, J. W., Horwitz, R. I, \& McEwen, B. S. (1997). Price of adaptation - allostatic load and its health consequences: MacArthur studies of successful aging. Archives of Internal Medicine, 157(19), 2259-2268.

Seng, H. (2009). Predicting age using biomarkers and physiological measurements. Journal Biomedical Information, 2009, 1-5.

Shah, D. J., Sachs, R. K., \& Wilson, D. J. (2012). Radiation-induced cancer: A modern view. The British Journal of Radiology, 85(1020), e1166-e1173.

Shi, X., Mothersill, C., \& Seymour, C. (2016). No adaptive response is induced by chronic low-dose radiation from Ra-226 in the CHSE/F fish embryonic cell line and the HaCaT human epithelial cell line. Environmental Research, 151, 537-546.

Shibamoto, Y., \& Nakamura, H. (2018). Overview of biological, epidemiological, and clinical evidence of radiation hormesis. International Journal of Molecular Sciences, 19(8), 2387.

Skivka, L. M., Fedorchuk, O. G., Khranovska, N. M., Rudyk, M. P., \& Opeida, I. V. (2015b). Diurnal variation in functional reserve and metabolic polarization of circulating monocytes in healthy men: 5.09. European Journal of Clinical Investigation, 45, 49-50.

Skivka, L. M., Fedorchuk, O. G., Susak, Y. M., Susak, M. Y., Malanchuk, O. M. Rudyk, M. P., \& Nowicky, Y. W. (2015a). Physical activity interferes with the immunomodulatory effect of the antineoplastic drug NSC631570. Current Pharmaceutical Biotechnology, 16(1), 49-59.

Sokolenko, V. (2016b). Znachennia henetychnykh system AB0, Rh ta Hp u stresindukovanii imunoreaktyvnosti meshkantsiv terytorii, zabrudnenykh radionuklidamy [The value of genetic systems AB0, Rh and Hp in stress-induced immunoreactivity among residents living in the areas contaminated with radionuclides]. Lesya Ukrainka Eastern European National University Scientific Bulletin, Series Biological Sciences, 332, 142-147 (in Ukrainian).

Sokolenko, V. L. (2016a). Pokaznyky kholesterynu ta imunnoyi systemy u osib z oznakamy veheto-sudynnoyi dystoniyi, shcho prozhyvaly na terytoriyakh, zabrudnenykh radionuklidamy [Cholesterol rate and immune system indices in people with symptoms of vegetative-vascular dystonia, who lived in the territories contaminated with radionuclides]. World of Medicine and Biology, 2, 86-90 (in Ukrainian).

Sokolenko, V. L., \& Sokolenko, S. V. (2015). Aktyvnist radionuklidiv i realizetsiia funktsii imunnoi systemy u meshkantsiv radiatsiino zabrudnenykh terytorii [Radionuclide activity and the immune system functioning in residents of radiation contaminated areas]. Regulatory Mechanisms in Biosystems, 6(2), 93-96 (in Ukrainian). 
Sokolenko, V. L., \& Sokolenko, S. V. (2016). Vplyv pomimykh fizychnykh navantazhen na pokaznyky imunnoi systemy u meshkantsiv radiatsiino zabrudnenykh terytorii [Influence of moderate physical load on parameters of the immune system among residents of contaminated areas]. Regulatory Mechanisms in Biosystems, 7(1), 48-52.

Sokolenko, V. L., \& Sokolenko, S. V. (2017a). Vzaiemozviazok pokaznykiv imunnoi systemy ta tyreoidnoho statusu v osib z radiatsiino-zabrudnenykh terytorii za umov psykhoemotsiinoho navantazhennia [Interactions between immune system parameters and thyroid status in people from radioactive contaminated areas by the conditions of emotional stress]. Fiziolohichnyi Zhurnal, 63(3), 3239 (in Ukrainian)

Sokolenko, V. L., \& Sokolenko, S. V. (2017b). Vzaiemozviazok lipidnoho obminu ta tyreoidnoho statusu za prolonhovanoho vplyvu malykh doz radiatsii [The interaction between lipid exchange and thyroid status in the conditions of prolonged influence of small doses of radiation]. Regulatory Mechanisms in Biosystems, 8(2), 231-238 (in Ukrainian).

Sokolenko, V. L., \& Sokolenko, S. V. (2017c). Znachennia statevoho faktora u realizatsii okremykh pokaznykiv imunnoi, endokrynnoi system ta lipidnoho obminu za umov prolonhovanoho vplyvu malykh doz radiatsii [The importance of gender factor in realization of significant parameters of the immune and endocrine systems, and also lipid metabolism, in conditions of prolonged effect of low dose radiation]. Visnyk Problem Biolohii i Medytsyny, 135, 412-416 (in Ukrainian).

Sokolenko, V. L., \& Sokolenko, S. V. (2019). Interdependence of oxidative/antioxidant system indicators and thyroid status under conditions of prolonged exposure to small doses of radiation. Regulatory Mechanisms in Biosystems, $10(2), 219-227$.

Sokolenko, V. L., Sokolenko, S. V., Sheiko, V. I., \& Kovalenko, O. V. (2018). Interconnection of the immune system and the intensity of the oxidative processes under conditions of prolonged exposure to small doses of radiation. Regulatory Mechanisms in Biosystems, 9(2), 167-176.

Sokolov, M., \& Neumann, R. (2016). Global gene expression alterations as a crucial constituent of human cell response to low doses of ionizing radiation exposure. International Journal of Molecular Sciences, 17(1), 55.

Somero, G. N., Lockwood, B. L., \& Tomanek, L. (2017). Biochemical adaptation: Response to environmental challenges, from life's origins to the anthropocene. Sinauer Associates Incorporated Publishers.

Sonnentag, S., \& Fritz, C. (2006). Endocrinological processes associated with job stress: Catecholamine and cortisol responses to acute and chronic stressors. In: Perrewe, P., \& Ganster, D. (Ed.). Employee health, coping and methodologies. Emerald Group Publishing Limited, Bingley. Pp. 1-59.

Sumner, D. (2007). Health effects resulting from the Chernobyl accident. Medicine, Conflict and Survival, 23(1), 31-45.

Szyf, M., \& Pluess, M. (2015). Epigenetics and well-being: Optimal adaptation to the environment. In: Pluess, M. (Ed.). Genetics of psychological well-being. Oxford University Press, Oxford. Pp. 211-230.

Tang, F. R., Loke, W. K., \& Khoo, B. C. (2016). Low-dose or low-dose-rate ionizing radiation-induced bioeffects in animal models. Journal of Radiation Research, 58(2), 165-182.

Vaiserman, A., Koliada, A., \& Socol, Y. (2019). Hormesis through low-dose radiation. In: Rattan, S. I. S., \& Kyriazis, M. (Eds.). The science of hormesis in health and longevity. Academic Press. Pp. 129-138.

Ventura, M. T., Casciaro, M., Gangemi, S., \& Buquicchio, R. (2017). Immunosenescence in aging: Between immune cells depletion and cytokines upregulation. Clinical and Molecular Allergy, 15(1), 21.
Voitenko, V. P. (1987). Matematicheskoe modelirovanie v gerontologii [Mathematical modeling in gerontology]. In: Gerontology and geriatry. Annual book: Immunity and aging. Kyiv. Pp. 118-130 (in Russian).

Voitenko, V. P., Tokar', A. V., Rudaya, E. S., Kolodchenko, V. P., Ena, L. M., Lanovaya, V. B., Ahaladze, N. G., Persidskiy, I. V., \& Chernyavskaya, A. A. (1989). Opredelenie biologicheskogo vozrasta kak problema nenozologicheskoy diagnostiki [Determination of biological age as a problem of nonnosological diagnosis]. In: Medicobiological and social aspects of aging: Problems of gerontology. Vol. 11. Kyiv. Pp. 9-14 (in Russian).

Wajapeyee, N., Serra, R. W., Zhu, X., Mahalingam, M., \& Green, M. R. (2008). Oncogenic BRAF induces senescence and apoptosis through pathways mediated by the secreted protein IGFBP7. Cell, 132(3), 363-374

Weksler, M. E., \& Szabo, P. (2000). The effect of age on the B-cell repertoire. Journal of Clinical Immunology, 20(4), 240-249.

Wikby, A., Ferguson, F., Forsey, R., Thompson, J., Strindhall, J., Löfgren, S., Nilsson, B. O., Ernerudh, J., Pawelec, G., \& Johansson, B. (2005). An immune risk phenotype, cognitive impairment, and survival in very late life: Impact of allostatic load in Swedish octogenarian and nonagenarian humans. The Journals of Gerontology Series A: Biological Sciences and Medical Sciences, 60(5), 556-565.

Wikby, A., Nilsson, B. O., Forsey, R., Thompson, J., Strindhall, J., Löfgren, S., Ernerudh, J., Pawelec, G., Ferguson, F., \& Johansson, B. (2006). The immune risk phenotype is associated with IL-6 in the terminal decline stage: Findings from the Swedish NONA immune longitudinal study of very late life functioning. Mechanisms of Ageing and Development, 127(8), 695-704.

Wiley, C. D., Velarde, M. C., Lecot, P., Liu, S., Sarnoski, E. A., Freund, A., Shirakawa, K., Lim, H. W., Davis, S. S., Ramanathan, A., Gerencser, A. A., Verdin, E., \& Campisi, J. (2016). Mitochondrial dysfunction induces senescence with a distinct secretory phenotype. Cell Metabolism, 23(2), 303-314.

Wiley, J. F., Gruenewald, T. L., Karlamangla, A. S., \& Seeman, T. E. (2016). Modeling multisystem physiological dysregulation. Psychosomatic Medicine, 78(3), 290-301.

Xia, X., Chen, W., McDermott, J., \& Han, J. D. J. (2017). Molecular and phenotypic biomarkers of aging. Version 1. F1000Research, 6, 860 .

Yang, E. V., \& Glaser, R. (2002). Stress-induced immunomodulation and the implications for health. International Immunopharmacology, 2(2-3), 315-324.

Yankner, B. A., Lu, T., \& Loerch, P. (2008). The aging brain. Annual Review of Pathology: Mechanisms of Disease, 3, 41-66.

Zaporozhan, V. M., Bazhora, Y. I., Kresiun, V. Y., Vorokhta, Y. M., Marichereda, V. H., \& Chesnokova, M. M. (2010). Molekuliarna epidemiolohiia [Molecular epidemiology]. Odeskyi Derzhavnyi Medychnyi Universytet, Odesa (in Ukrainian).

Zaretskaya, Y. M. (1983). Klinicheskaya immunogenetika [Clinical immunogenetics]. Meditsina, Moscow (in Russian).

Zölzer, F., Havránková, R., Skalická, Z. F., Rössnerová, A., \& Šrám, R. J. (2015). Analysis of genetic damage in lymphocytes of former uranium processing workers. Cytogenetic and Genome Research, 147(1), 17-23.

Zölzer, F., Hon, Z., Skalická, Z. F., Havránková, R., Navrátil, L., Rosina, J., \& Škopek, J. (2012). Micronuclei in lymphocytes from currently active uranium miners. Radiation and Environmental Biophysics, 51(3), 277-282.

Zölzer, F., Kř̌̌žová, M., Freitinger Skalická, Z., Rössnerová, A., \& Šrám, R. (2017). Micronucleus frequency and content in healthy relatives of cancer patients. Biomarkers, 22(7), 667-673. 